\title{
Effect of Nano-Silica on Consolidation and Permeability Properties of Lateritic Soil
}

\author{
${ }^{1 *}$ Ochepo, J. and ${ }^{2}$ Kanyi, I. M. \\ ${ }^{1}$ Department of Civil Engineering Ahmadu Bello University, Zaria, Nigeria \\ ${ }^{2}$ Department of Civil Engineering University of Agriculture, Makurdi, Benue State, Nigeria. \\ *Corresponding Author E-mail: ochepo1@gmail.com Tel:+2348038903622
}

\begin{abstract}
A reddish-brown lateritic soil obtained from Zaria; Nigeria was treated with up to $2.5 \%$ nano-silica. Consolidation properties (i.e. Pre-consolidation pressure, compression index, coefficient of volume compressibility and coefficient of consolidation) of treated specimens were assessed using one dimensional consolidation test. The permeability property of treated soil was also evaluated. The results obtained showed that the pre-consolidation pressure generally increased with increasing percentage of nano-silica content and curing time. The compression index $\left(C_{c}\right)$ increased steadily with higher percentage of nano-silica contents up to 2.5\% treatment for 7 and 14 days of curing, but decreased after 28 days curing period. The recompression index $\left(C_{r}\right)$ on the other hand generally increased with increase percentage of nano-silica content and curing period. The coefficient of volume compressibility $\left(M_{v}\right)$ did not follow any definite trend, but at $2.5 \%$ nano-silica content, the $M_{v}$ decreased for all curing periods considered. The coefficient of consolidation $\left(C_{v}\right)$ also, did not give a definite trend with increase in nano-silica content, suggesting that increasing the amount of nano-silica content in the soil has little or no impact on the time rate of settlement. The coefficient of permeability $(k)$ decreased as the soil was treated with nano-silica especially beyond loading pressure of $40 \mathrm{kN} / \mathrm{m}^{2}$. This study showed that nano-silica (up to 2.5\%) can be used to stabilize lateritic soil to improve its consolidation properties.
\end{abstract}

Keywords: Nano-silica, Lateritic soil, Consolidation, Coefficient of volume compressibility, Preconsolidation pressure, Coefficient of permeability.

\section{Introduction}

Soil is considered a key component in the construction industry. The success of any given structure lies in stability of the underlain soil. When soil condition of a particular site is good, the implementation of the planned project does not require soil improvement. However, when faced with poor in-situ soil condition, the geotechnical engineer has some key decisions to make among which include; replacement of the undesired soil with competent soil material, redesign of the intended structure, changing the location of project or enhancing the poor soil with chemical or additives (in-situ stabilization).

Chemical stabilization of soils using additive such as cement and lime is an age long method used in civil engineering for the improvement of soil properties (Choobbasti et al., 2014; Sarokolayi et al., 2015a, b; Mashhadban et al., 2016a, b). However, the problem of the rising cost of these additives as well as the environmental pollution associated with their production has been a source of great concern which necessitate the need for consideration of alternatives that can be used. One of such alternatives is the use of nano-silica derived from nanotechnology.

Nanotechnology has been defined as the control, comprehension, and reformation of material based on the hierarchy of nano-meters to develop matter with essentially new uses and a new constitution, (NSTC, 2007). The application of nanotechnology in diverse field of engineering is demonstrated through research and is well documented in literature (Lv et al., 2019). Nanotechnology is capable of creating products with distinctive properties which can be employed in civil engineering in 
enhancing the performance of construction materials such as; improved cementious ability, rate of fire resistance, coatings etc, (Lee et al., 2010; Ganesh, 2012; Saurav, 2012). In geotechnical engineering, the technology is applied by introducing nanoparticles to the soil with a view of enhancing the overall engineering performance of the targeted soil. Some researchers (Ghazi et al., 2011; Alireza et al., 2013; Pham and Nguyen, 2014; Ramesh and Chandrika, 2017; Eswaramoorthi et al., 2017; Ran et al., 2018; Al-Swaidani et al., 2019) have used nanoparticles to enhance engineering behaviour of marginal soils. The introduction of nano particles into the soil alters the chemical as well as the physical behaviour of the soil owing largely to increased specific surface of particles at nano level, morphological changes as well as increased surface charges (Salwa et al., 2015).

Nano-silica has come to be used widely as a composite material in geotechnical engineering in recent years and is known for its excellent properties of small particle size, porous and large surface area. Research on pozzolanic activity of nano-silica particles indicated a high pozzolanic activity compared to micro silica level (Li, 2004). Furthermore, since silica nanoparticles act as an accelerator, structure of cementitious materials becomes denser and more uniform even in a short time of curing ( $\mathrm{Li}, 2004)$.

Many studies carried out to investigate the effect of nano-silica on properties of deficient soils showed significant improvement. For example, a study carried out to explored the influence of nanosilica particles on the unconfined compressive strength, UCS, hydraulic conductivity, and Atterberg limits of cemented clay showed that the inclusion of nano-silica particles leads to a reduction in plasticity index and an improvement in soil strength (Bahmani et al., 2014). Ghasabkolaei et al. (2016) investigated the effect of nanoparticle on the unconfined compression and California bearing ratio (CBR) of cement-stabilized clayey soil. They found that the addition of $1.5 \%$ nano-silica improves the UCS of the cemented clay. Choobbasti et al. (2015) reported an increase in UCS with increase in nano-silica content when they conducted a series of unconfined compression tests to investigate the mechanical properties of sandy soils stabilized with Portland cement and nanoparticles. Papatzani et al. (2014) investigated the impact of the inclusion of nano-silica on the microstructure characteristics and strength of blended Portland cement pastes. They reported that the microstructure properties of cement paste are improved with addition nano-silica.

Lateritic soils are formed as a results of weathering processes in the tropic. These soils are formed by leaching out basic oxides leaving behind sesquioxides of iron and aluminium and other trace compounds within the given laterite soil profile (Gidigasu, 1976). The reddish-brown soils are found in abundance in Nigeria and are usually employed in road and other areas of construction industry. Lateritic soils are considered poor when the clay content is high leading to high dust generation in the dry season and production of slippery (unstable) surfaces during the rainy season. A number of studies have been carried out in area of stabilization of tropical lateritic soils with various additive such as cement, lime, fly ash (Osinubi, et. al., 2007a, b; Nicholson, et. al., 1994). Laterite soil obtained from Zaria Nigeria has been studied extensively with a number of additives employed in the stabilization of the soil for engineering application (Osinubi, 1998a, b; Osinubi and Nwaiwu, 2006). In this study, the consolidation and permeability properties of laterite soil obtained from Zaria, Kaduna state, Nigeria, was investigated after treatment with nano-silica up to $2.5 \%$ in consideration for used as fill material for embankment.

\section{Materials and Methods Materials}

Soil: Lateritic soil was obtained from Shika (Longitude $7^{\circ} \mathrm{N} 45^{\prime}$ E Latitude $11^{\circ} 15^{\prime} \mathrm{N}$ ) in Zaria by bulk sampling technique. The geologic formation of the area falls under the ferruginous tropical soil 
which is a product of acid igneous and metamorphic rocks (Akintola, 1982). The clay mineral kaolinite dominates this laterite formation (Osinubi, 1998).

Nano-Silica: Nano $\mathrm{SiO}_{2}$ (Levasil CB8) in solution form was gotten from Akzo Nobel, Pulp and Performance Chemical AB (China). Levasil CB8 is an alkaline, aqueous dispersion of colloidal silica that is in approximately $50 \%$ solid by weight (see $\mathrm{T}$ able 1 ). The silica dispersion is sodium stabilized and the amorphous silica particles carrying a surface charge. The $\mathrm{SiO}_{2}$ particles are discrete, have a smooth, spherical shape, and are present in a wide particle size distribution.

Table 1: Typical Properties of Levasil CB8

\begin{tabular}{lc}
\hline Properties & Value \\
\hline Silica $(\mathrm{wt} \%)$ & $50 \%$ \\
$\mathrm{pH}$ & 9.5 \\
Viscosity, $(\mathrm{cP})$ & 8 \\
Density $\left(\mathrm{g} / \mathrm{cm}^{3}\right)$ & 1.4 \\
$\mathrm{Na}_{2} \mathrm{O}(\mathrm{wt} \%)$ & 0.2 \\
\hline
\end{tabular}

*Source: www.akzonobel.com/colloidalsilica

\section{Methods}

Index properties: The index properties which include Atterberg limits, specific gravity, natural moisture content and sieve analysis tests were carried out in line with BS 1377 (1990) part 2.

Compaction: Soil samples passing through sieve $4.75 \mathrm{~mm}$ aperture (sieve number 4) were blended with $0,0.5,1,1.5,2$ and 2.5 percent Nano silica content and compacted with British Standard light (BSL) compaction energy following British Standards 1377 (1990) procedures.

Consolidation: One dimensional consolidation test was carried out on the test samples. The natural and treated lateritic soil samples were compacted at optimum moisture content, and were sealed within air tight polythene bags. The samples were cured for 7, 14 and 28 days after which the specimens were cored into the Oedometer ring and placed in the consolidometer setup. Pressure increment was $10 \mathrm{kN} / \mathrm{m}^{2}, 20 \mathrm{kN} / \mathrm{m}^{2}, 40 \mathrm{kN} / \mathrm{m}^{2}, 80 \mathrm{kN} / \mathrm{m}^{2}$ and $160 \mathrm{kN} / \mathrm{m}^{2}$ during the loading stage and unloaded up to $10 \mathrm{kN} / \mathrm{m}^{2}$. Compression readings were recorded between $10 \mathrm{sec}$ and 24 hours during the loading stage for each incremental load. The Taylor method (Square Root of Time Method) was used to analyze experimental results and the pre-consolidation pressure was obtained from the void ratio-pressure curve using the procedure proposed by Casagrande (1936)

Permeability: The permeability of the soil was evaluated from the results obtained from the onedimensional consolidation test.

\section{Results and Discussion}

Index properties: The results of the index properties of the natural soil as well as the particle size distribution are presented in Table 2 and Figure 1 respectively. From Table 1, the liquid limit (LL), plastic limit, (PL) and Plasticity index, (PI) of the soil were 45, 25 and 19\% respectively. The result of the particle size analysis shows that the percentage fine was $58 \%$ indicating that the soil is fine grained. The physical appearance of the soil shows reddish brown colour. These test results show that the soil belongs to the CL group in the Unified Soil Classification (USC) System (ASTM, 1992) and A-7-6 soil in the American Association of State Highway and Transportation Officials, (AASHTO) Soil classification system (AASHTO, 1986). Soil in this group are general poor for engineering subgrade use. 


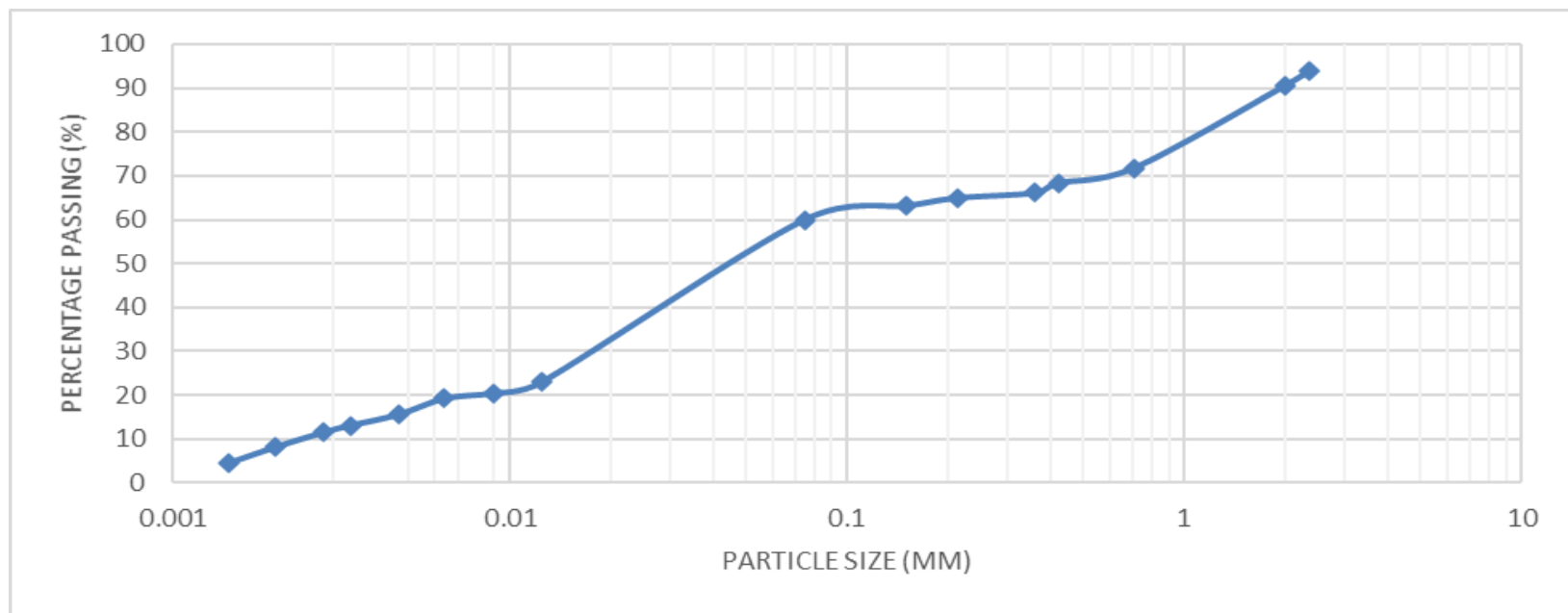

Figure 1: Particle Size Distribution of the Natural Lateritic Soil

Table 2: Natural properties of lateritic soil

\begin{tabular}{ll}
\hline Soil Properties & Test Result \\
\hline Colour & Reddish-brown \\
Dominant Clay Mineral & Kaolinite \\
Natural Moisture Content (\%) & 7.0 \\
Percentage Passing BS Sieve No 200 (\%) & 58.6 \\
AASHTO Classification & A-7-6 \\
USCS Group & $\mathrm{CL}$ \\
Liquid Limit (\%) & 45 \\
Plastic Limit (\%) & 26 \\
Plasticity Index & 19 \\
Pre-Consolidation Pressure $\left(\mathrm{kN} / \mathrm{m}^{2}\right)$ & 93 \\
Compression Index & 0.0234 \\
Recompression Index & 0.0833 \\
\hline
\end{tabular}

Effect of nano-silica on pre-consolidation pressure: The variation of pre-consolidation pressure with increased percentage of nano-silica content at the different curing periods is shown in Figure 2. The pre-consolidation pressure increased from $93 \mathrm{kN} / \mathrm{m}^{2}$ for the natural soil to $103 \mathrm{kN} / \mathrm{m}^{2}, 110$ $\mathrm{kN} / \mathrm{m}^{2}, 115 \mathrm{kN} / \mathrm{m}^{2}$,

$118 \mathrm{kN} / \mathrm{m}^{2}$ and $120 \mathrm{kN} / \mathrm{m}^{2}$ when treated with $0.5,1,1.5,2$ and $2.5 \%$ nano-silica content and cured for 7 days respectively. Similar trends were observed for 14- and 28-days curing period although higher values were recorded with higher curing period. The 28 days curing recorded higher preconsolidation values (see figure 2). This implies that the soil is able to withstand increased pressures without settling at high nano-silica content.

The increase in pre-consolidation pressure could be as result of changes in mechanical behaviour of the treated soil due to nano-silica particles within the soil matrix which has high specific surface and hence increased reactivity leading to formation of strength enhancing compounds such as hydrated calcium silicates and aluminate (Salwa et al. 2015; Nabanita et al., 2016; Eswaramoorthi et al., 2017; Al-Swaidani et al., 2019). 


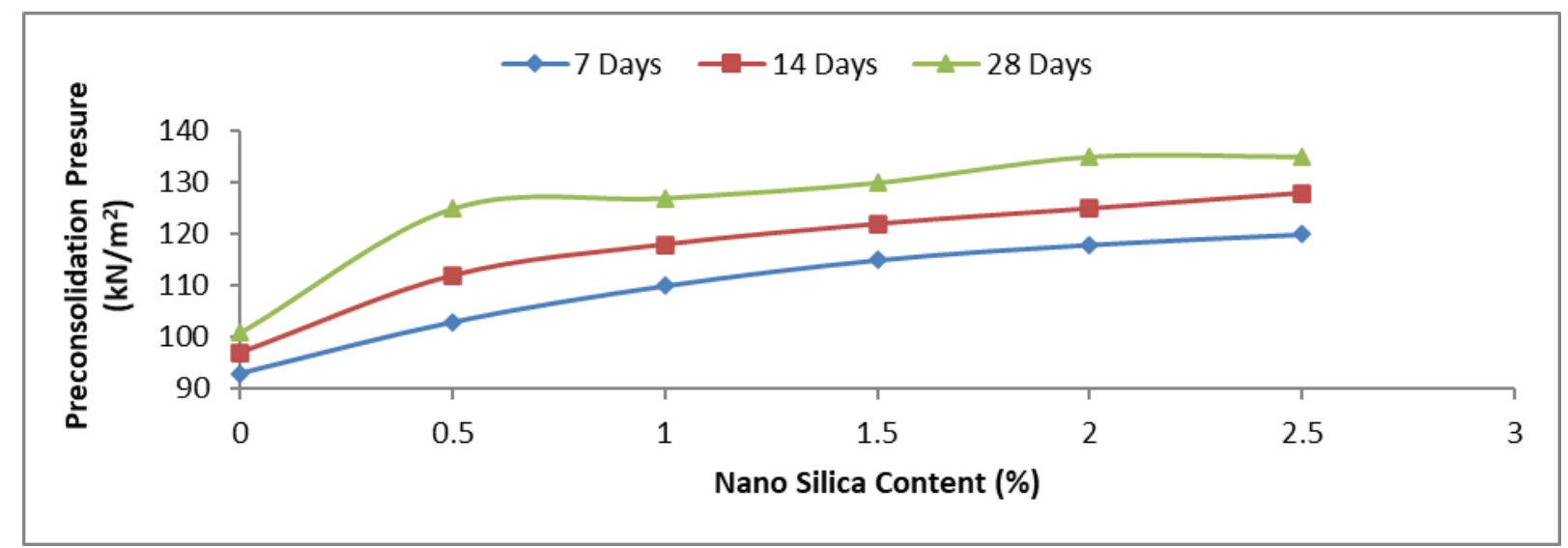

Figure 2: Variation of Pre-Consolidation Pressure with Nano-Silica Content at Different Curing Periods

Effect of nano-silica on compression Index: The variation of compression index, $\mathrm{Cc}$, with increased percentages of the nano-silica and different curing periods is shown in Figure 3 . The Compression index generally increased with increasing nano-silica content at 7- and 14-days curing periods but showed a decreasing trend at 28 days curing period. The Cc value of 0.0239 recorded for the natural soil increased to 0.0281 and 0.0286 at 7- and 14-days curing, while it decreased to 0.020 at 28 days curing when the soil was treated with $2.5 \%$ nano-silica content respectively. The observed trend at 28 days curing could be attributed to the increased formation of pozzolanic reaction products within the pore spaces of the treated lateritic soil over the longer curing period (28 days). These products which is essentially hydrated calcium silicate and aluminate gel, cements the soil particles together to form a strong soil matrix that is less susceptible to volume change under pressure hence the reduction in compression index (Eberemu 2011; Afolagboye and Talabi, 2013; Nabanita et al., 2016; Ran et al., 2018). Since the settlement of soils is directly related to the compression index, therefore, for optimum performance against settlement, it will be required that lateritic soil treated with nano-silica is allowed to cure for 28 days before major construction.

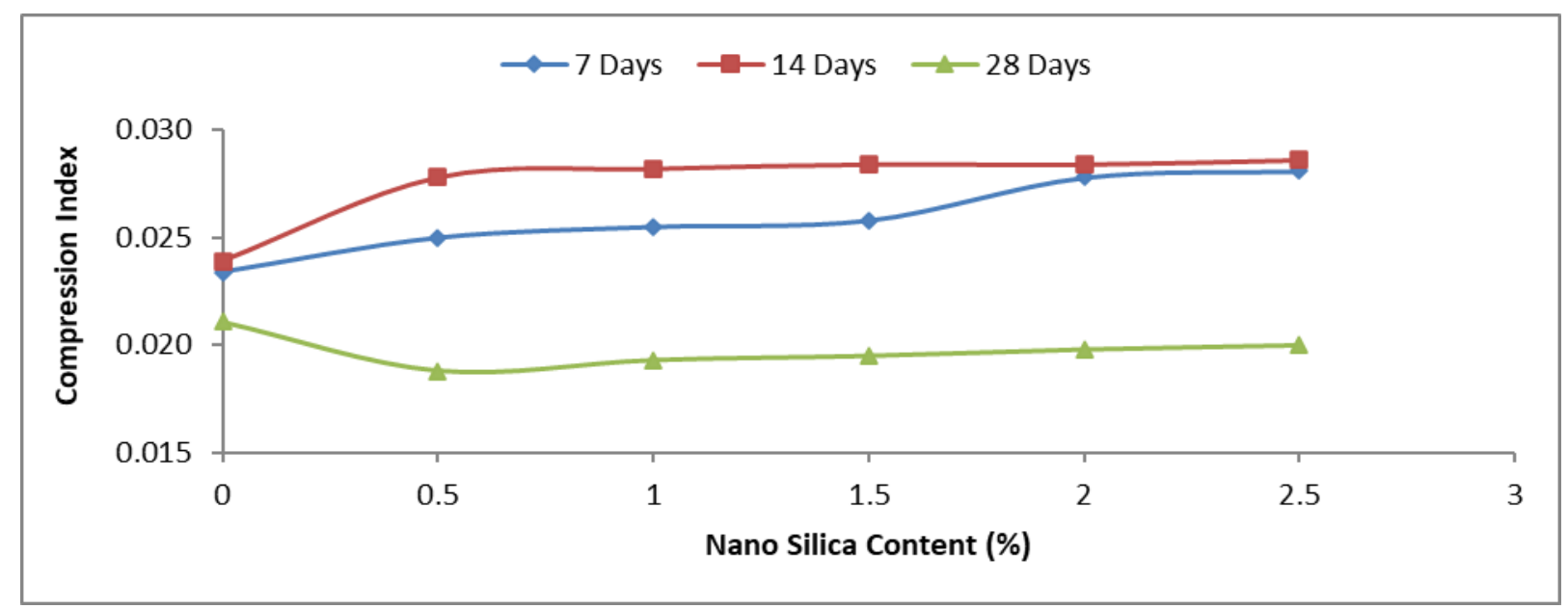

Figure 3: Variation of Compression Index with Nano-Silica Content at Different Curing Periods 
Effect of Nano-silica on Recompression index: The variation of recompression index with increased percentage of the nano-silica content at the different curing periods is shown in Figure 4. The recompression index values increased with increase in both nano-silica content as well as curing period. The recompression index values increased from 0.0833 for untreated soil to $0.0843,0.0843$ and 0.0844 at 7,14 - and 28 -days curing period respectively, after treatment with $2.5 \%$ nano-silica (see figure 4). The increase in recompression index may be due to rearrangement of the soil matrix and the cementing bond from the nano-silica. There may have been alteration of the cementing bond due to the rebound effect of the treated soil as it was relieved of the applied pressure. This effect could have led to reduction in strength and compactness of the treated soil leading to increasing in compressibility.

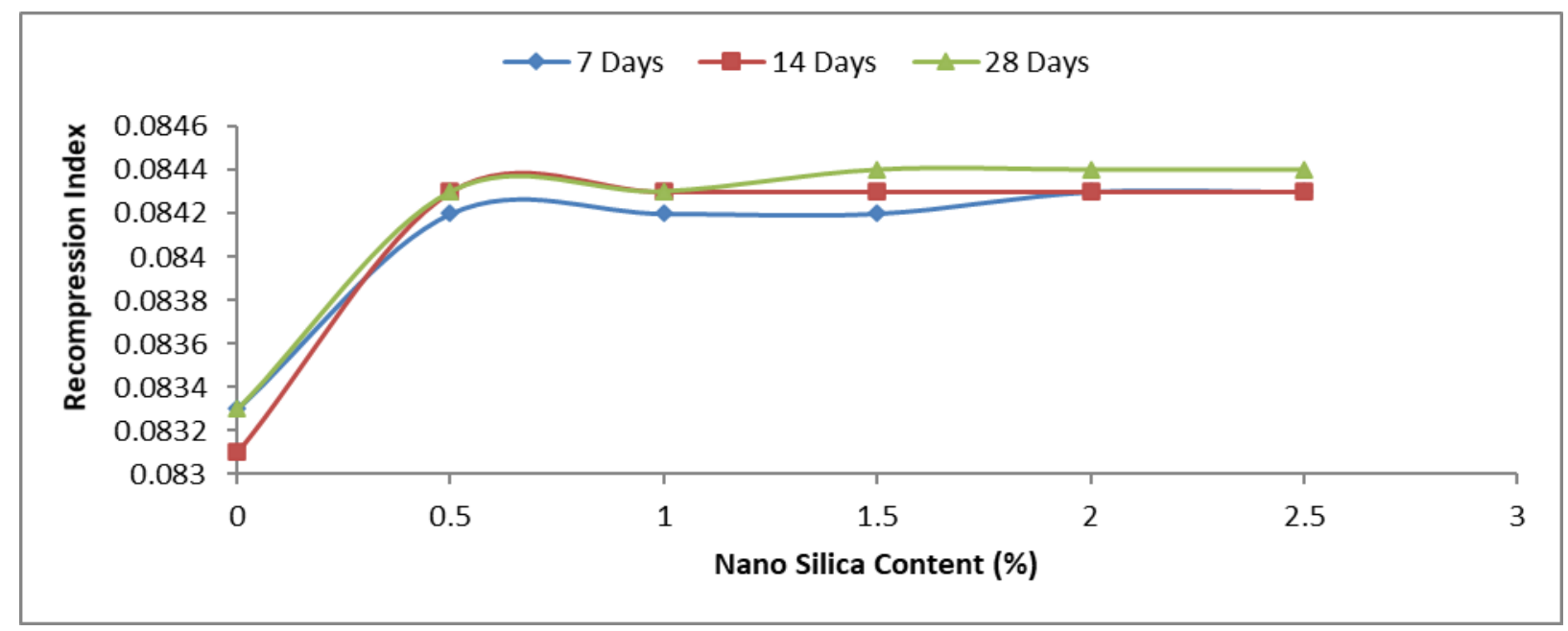

Figure 4: Variation of Recompression Index with Nano-Silica Content at Different Curing Periods

Effect of Nano-silica on coefficient of volume compressibility: The variation of coefficient of volume compressibility, $\left(\mathrm{M}_{\mathrm{V}}\right)$ with effective pressure of the lateritic soil treated with varying nanosilica content and cured for 7, 14 and 28 days is shown in Figure 5a, b and c. The coefficient of volume compressibility can be seen to decrease when nano-silica was added to the soil. This pattern although not consistent with nano-silica content was observed at all the curing periods. $\mathrm{M}_{\mathrm{v}}$ however shows a general decreasing trend as the effective pressure is increased for all the nano-silica content and curing periods. The values of $\mathrm{M}_{\mathrm{v}}$ ranged from $0.0484-0.0625,0.0377-0.0538,0.0483-$ $0.0565,0.0313-0.0377$ and $0.0351-0.0452$ at $10,20,40,80$ and $160 \mathrm{kN} / \mathrm{m}^{2}$ loadings respectively after treatment with $0.5-2.5 \%$ nano-silica content at 7 days curing period (see figure $5 \mathrm{a}$ ). Similar behaviour was observed after 14- and 28-days curing time (see figures 5 (b and c)).

It can also be seen in Figure 5(a, b and c) that the coefficient of volume compressibility, $\mathrm{M}_{\mathrm{v}}$, decreases with curing period. Lower values of $\mathrm{M}_{\mathrm{v}}$ were seen at 28 days curing. The possibility of this could be attributed to the pozzolanic reaction which is usually time dependent and continues with curing period under favourable conditions. As the reaction progress with time, more of the reaction product are formed which fill the voids and cement the soil particles together leading to reduction in coefficient of volume compressibility. Also, it might be connected to the individual particle rearrangement due to increasing pressure as well as increasing percentage of nano-silica content resulting to reduced inter-clod voids which ultimately leads to reduction in $\mathrm{M}_{\mathrm{v}}$ under loading condition (Kazemian and Huat, 2009; Afolagboye and Talabi, 2013; Nabanita et al., 2016). 


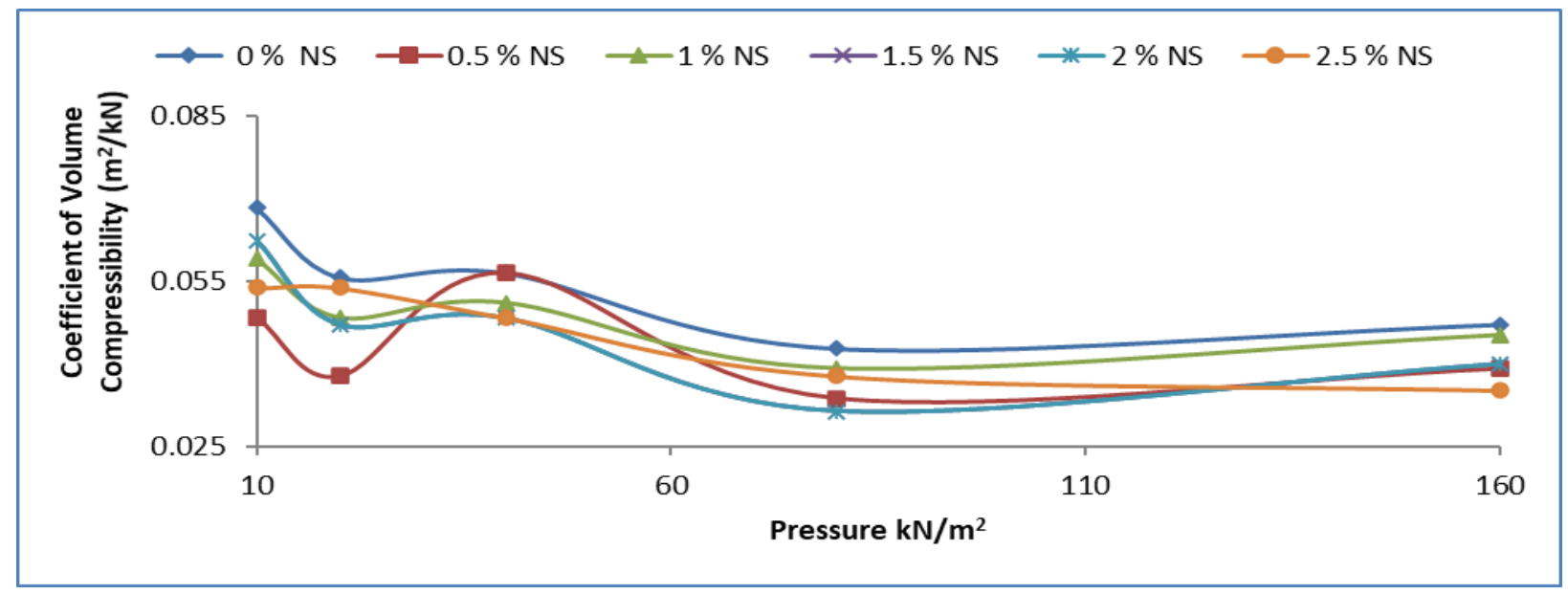

Figure 5a: Variation of Coefficient of Volume Compressibility with Pressure at 7 Days Curing Period

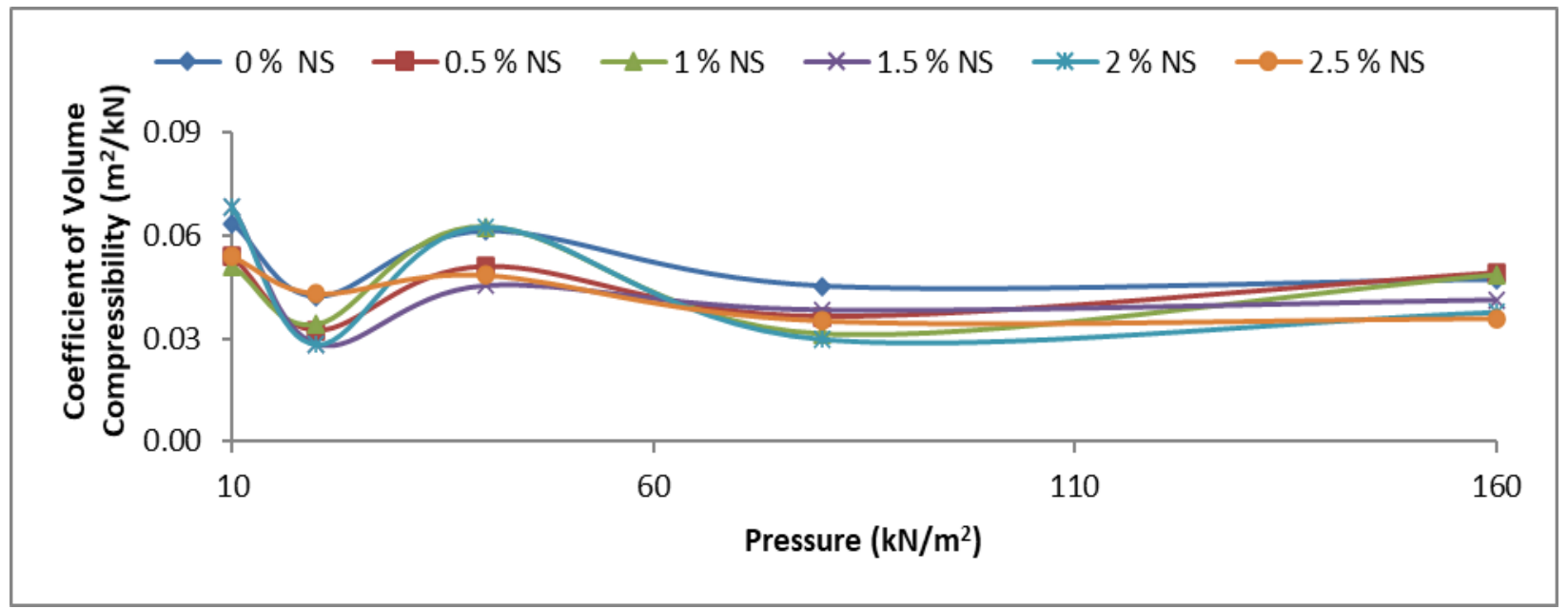

Figure 5b: Variation of Coefficient of Volume Compressibility with Pressure at 14 Days Curing Period

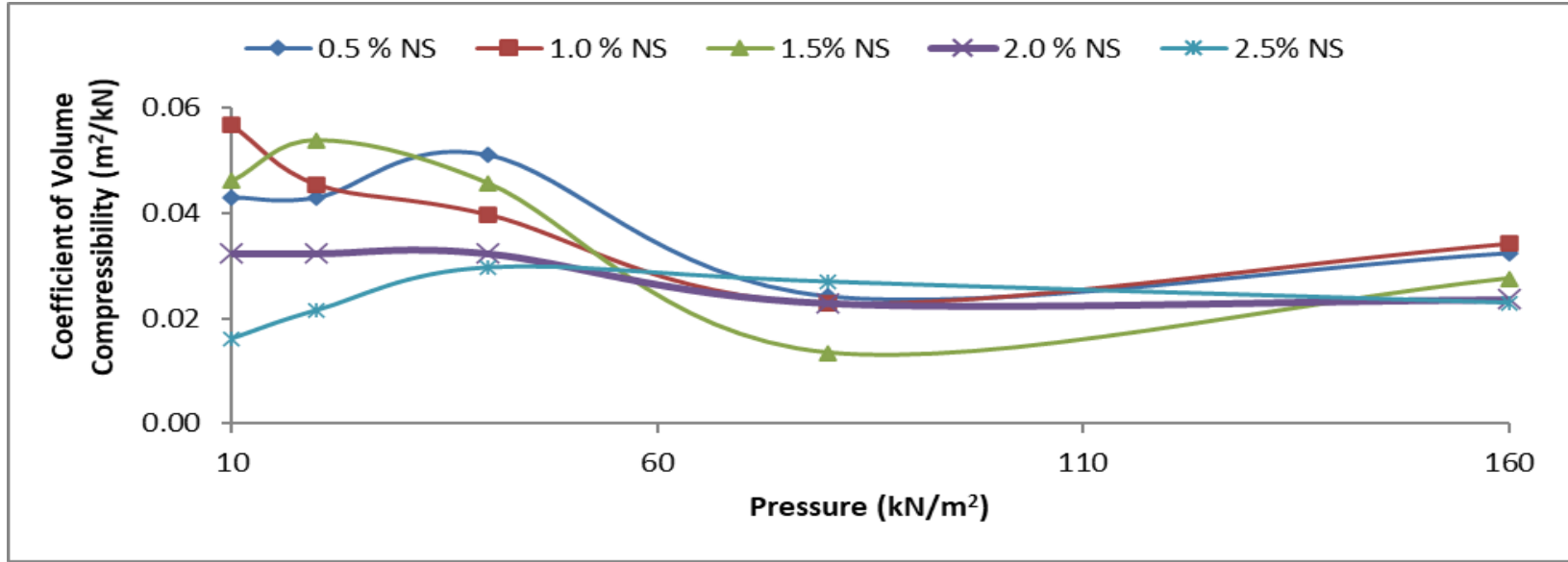

Figure 5c: Variation of Coefficient of Volume Compressibility with Pressure at 28 Days Curing Period 
Effect of Nano-silica on coefficient of consolidation $\left(\mathbf{C}_{\mathbf{v}}\right)$ : The variation of coefficient of consolidation. $\mathrm{Cv}$, with increased loading pressure at varying percentages of the nano-silica content and cured for 7, 14 and 28 days is shown in the Figure $6 \mathrm{a}, \mathrm{b}$ and c. No trend was observed on coefficient of consolidation with increased percentages of the nano-silica. This implies that increasing nano-silica content did not have a unique impact on the time rate of settlement. However, it was observed that there is a general decrease in $\mathrm{Cv}$ at higher pressure for all the curing periods and nano-silica content.

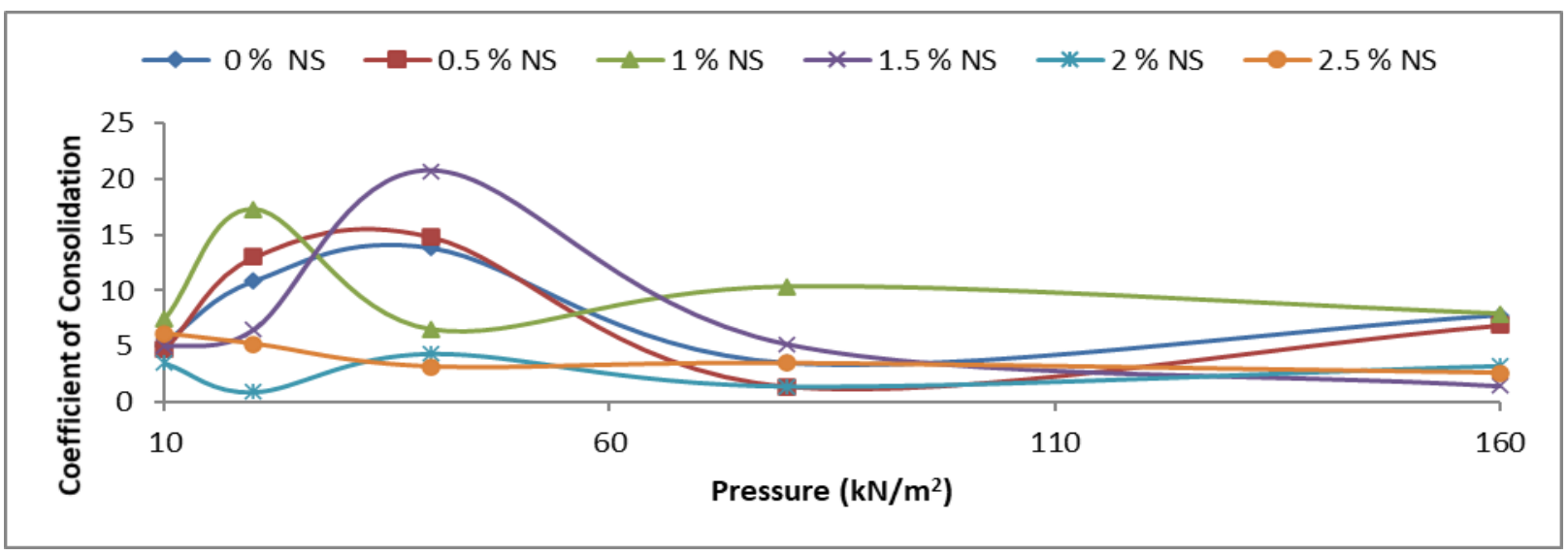

Figure 6a: Variation of Coefficient of Consolidation with Pressure at 7 Days Curing Period

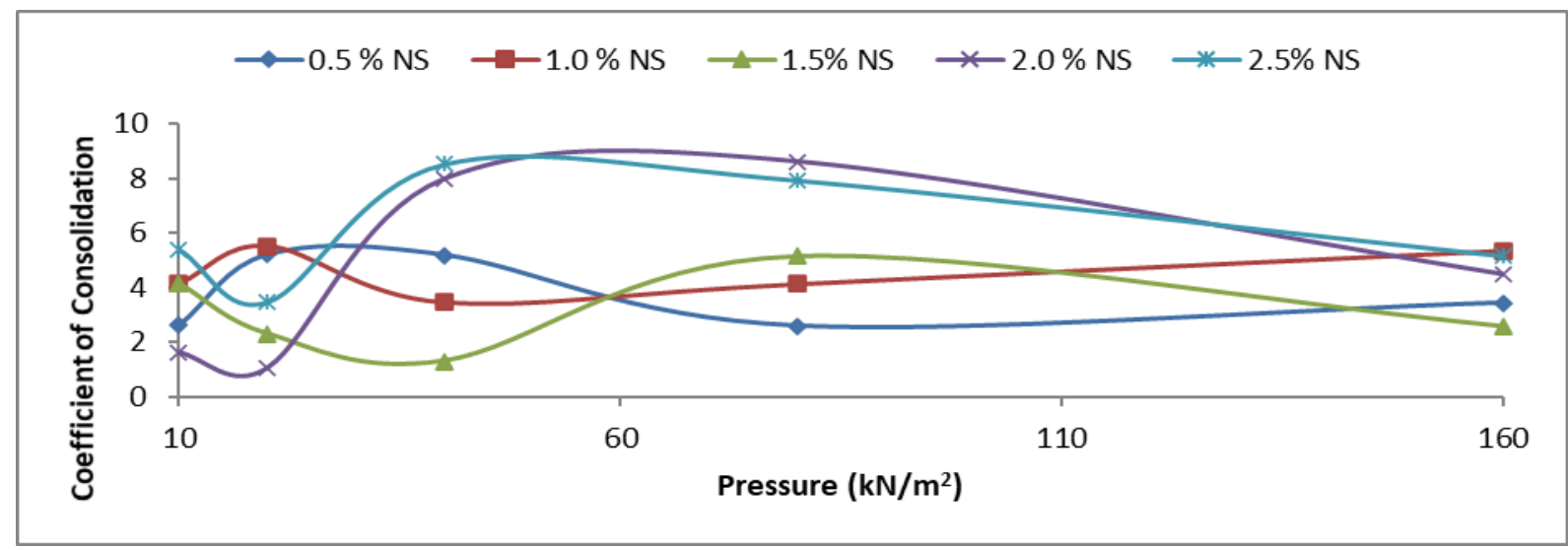

Figure 6b: Variation of Coefficient of Consolidation with Pressure at 14 Days Curing Period

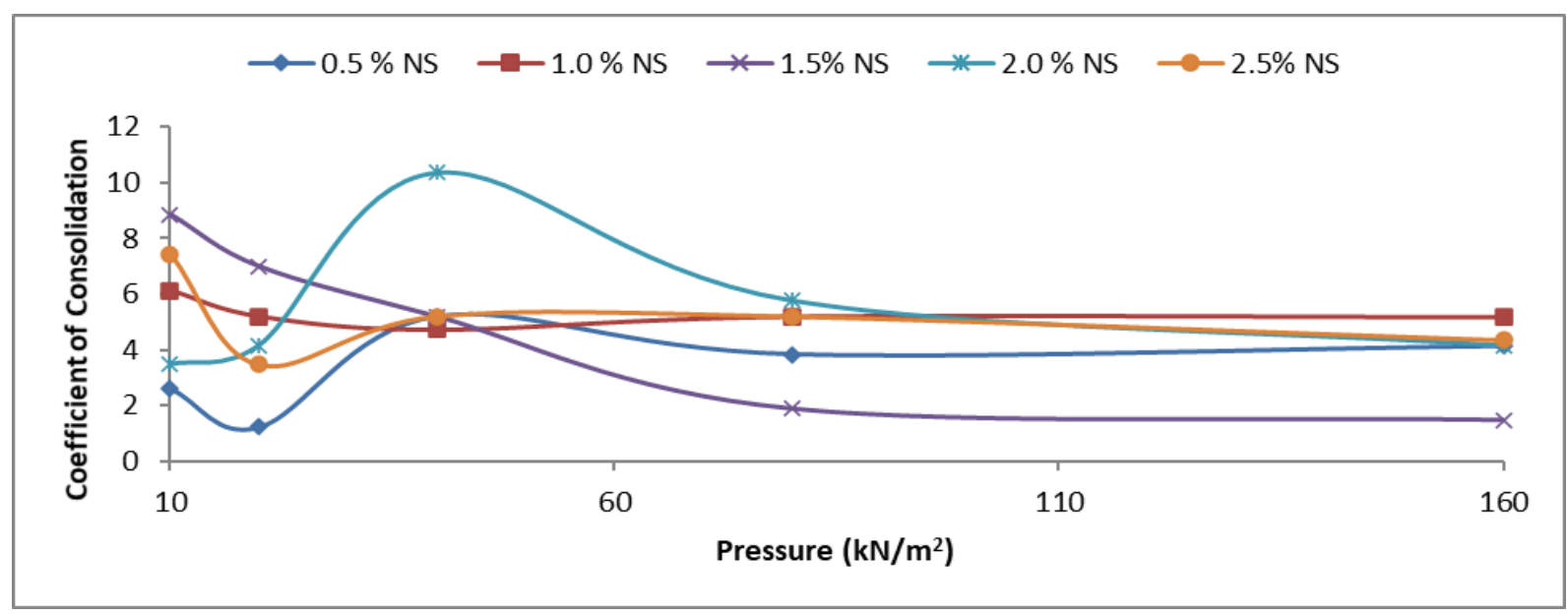

Figure 6c: Variation of Coefficient of Consolidation with Pressure at 28 Days Curing Period 
Effect of Nano-silica on Coefficient of Permeability (k): The variation of coefficient of permeability with increased loading pressure at varying percentages of the nano-silica content and cured for 7, 14 and 28 days is shown in the Figure 7a, b and c. There was no definite trend between coefficient of permeability with increase nano-silica content. However, a general decrease was observed at higher pressure especially beyond $40 \mathrm{kN} / \mathrm{m}^{2}$ when the soil was treated with nano-silica. This behaviour was consistent and more pronounced at 28 days curing period, (see figure $6 \mathrm{c}$ ). The increase in loading pressure results in physical rearrangements of soil particles and reduction of void spaces as the soil is compressed. The addition of nano-silica to the soil results in the formation of cementing products which occupies the interparticle voids and bind the soil particle together to form a strong matrix with less void spaces to allow for flow of water. because these reactions are time dependent, the more the curing periods, the more the reaction products that is formed and the more void spaces that is filled. These combine effect could be responsible for the low coefficient of permeability observed especially at 28 days curing period, (Figure $5 \mathrm{c}$ ).

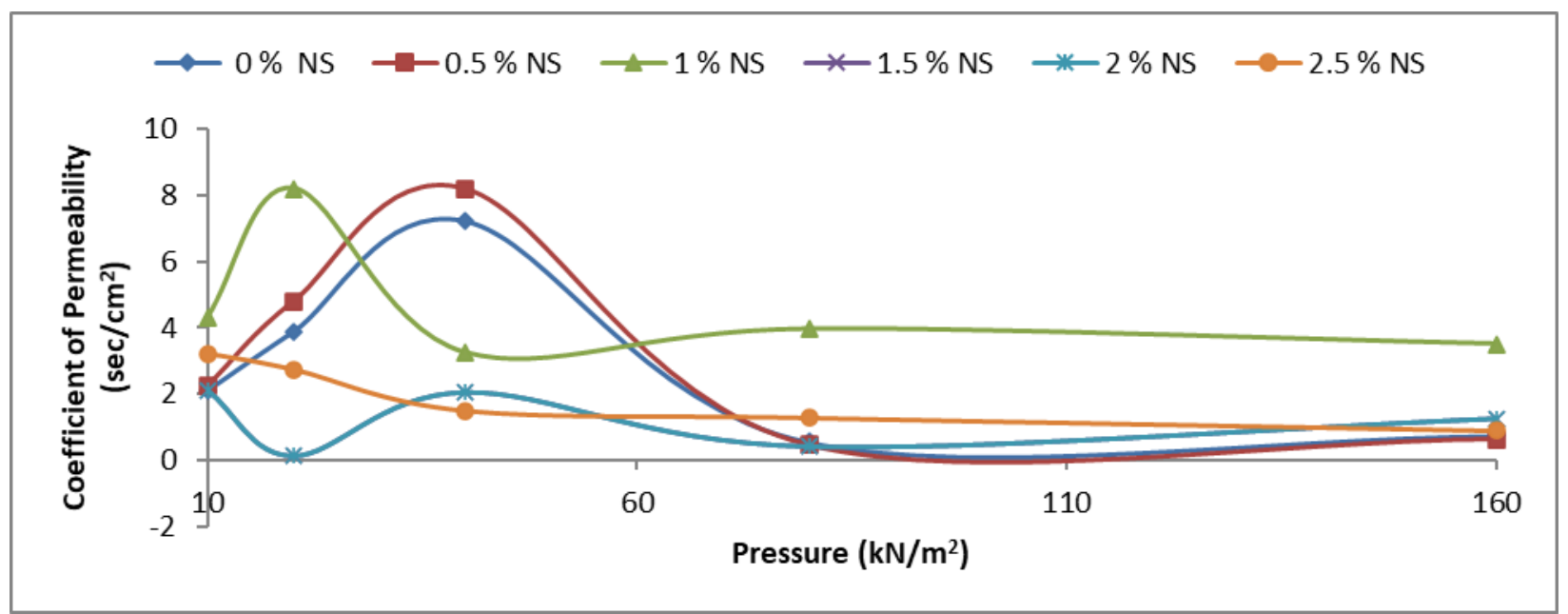

Figure 7a: Variation of Coefficient of Permeability with Pressure at 7 Days Curing Period

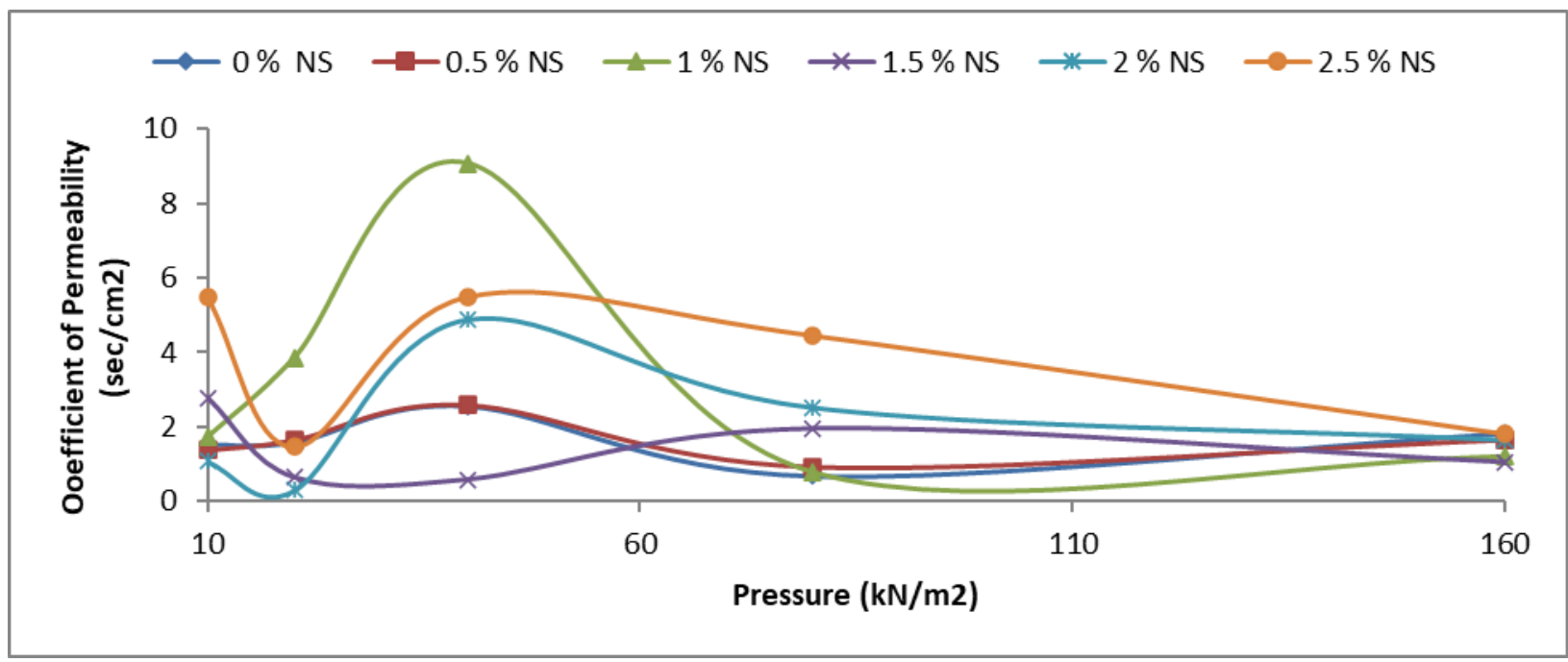

Figure 7b: Variation of Coefficient of Permeability with Pressure at 14 Days Curing Period 


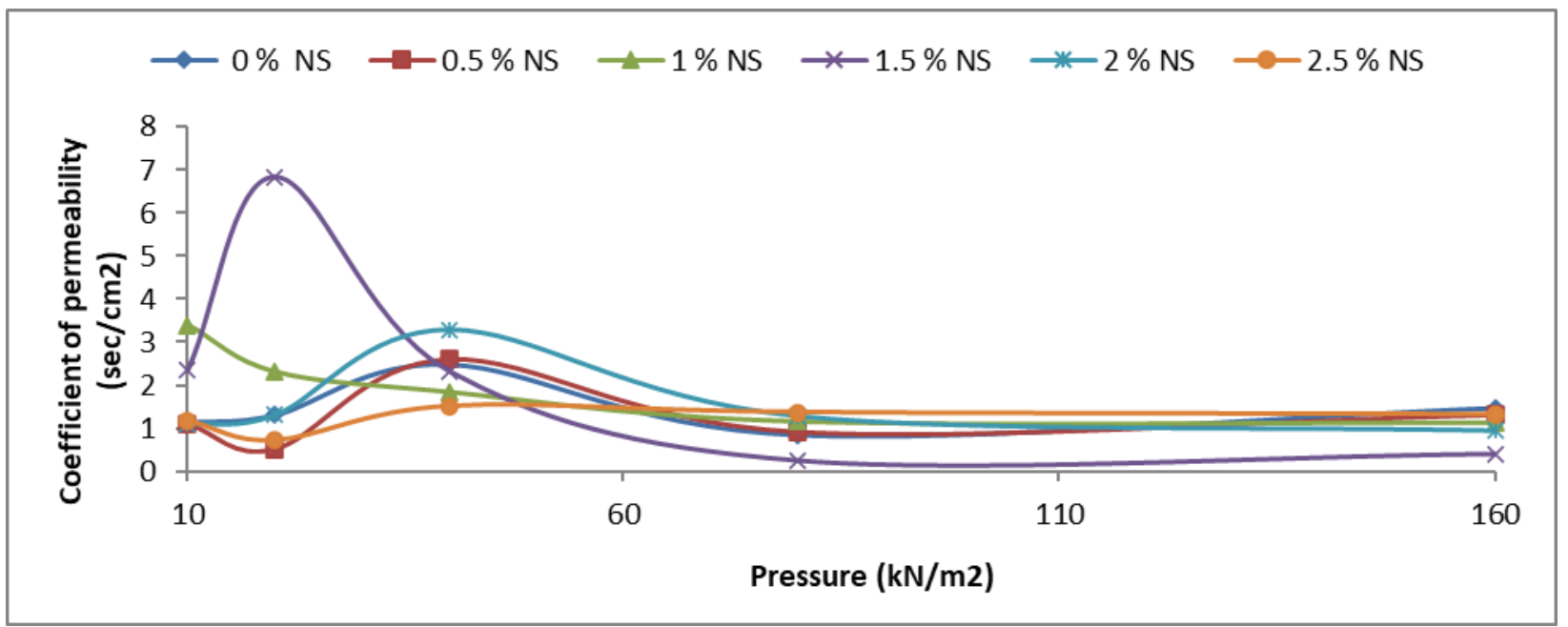

Figure 7c: Variation of Coefficient of Permeability with Pressure at 28 Days Curing Period

\section{Conclusion}

A reddish-brown lateritic soil was treated with nano-silica up to $2.5 \%$. Consolidation properties of treated specimens were assessed using one dimensional consolidation test. The permeability property of treated soil was also evaluated. The results obtained showed that:

i. The Pre-consolidation Pressure generally increased with increasing percentage of nanosilica treatment from 93, 97 and $101 \mathrm{kN} / \mathrm{m}^{2}$ to peak values of 120,123 and $135 \mathrm{kN} / \mathrm{m}^{2}$ respectively at $2.5 \%$ nano-silica at 7,14 - and 28 -days curing period.

ii. The Compression Index $\left(\mathrm{C}_{\mathrm{c}}\right)$ increased and peaked at 0.0281 and 0.0286 for samples cured for 7 and 14 days at 2.5\% nano-silica content. However, Cc decreased to 0.020 after 28 days curing period at same nano-silica content.

iii. The Recompression Index $\left(\mathrm{C}_{\mathrm{r}}\right)$ on the other hand generally increased with increasing percentage of nano-silica treatment and peaked at 0.0843 and 0.0844 beyond $1.5 \%$ nanosilica content for 7, 14 and 28 days curing.

iv. The Coefficient of volume compressibility $\left(\mathrm{M}_{\mathrm{v}}\right)$ did not follow any steady trend with nanosilica content but generally decreased as nano-silica was added to the soil and as the curing periods increased.

v. The Coefficient of consolidation $\left(\mathrm{C}_{\mathrm{v}}\right)$ did not give a definite trend with increase in nanosilica content suggesting that increasing the amount of nano-silica content in the soil has little or no impact on the time rate of settlement.

vi. No definite trend was established between the coefficient of permeability (k) and nano-silica content. However, $\mathrm{k}$ was observed to decrease as nano-silica was added to the soil and cured up to 28 days at pressure beyond $40 \mathrm{kN} / \mathrm{m}^{2}$.

vii. This study shows that nano-silica influence the consolidation as well as the permeability properties of the treated lateritic soil obtained from Zaria.

\section{References}

AASHTO (1986). Standard Specification for Transportation, Material and Methods of Sampling and Testing. 14th Edition. American Association of State Highway and Transportation official Washington D.C.

Afolagboye, O. L. and Talabi, A. O. (2013) Consolidation properties of compacted lateritic soil stabilized with tyre ash. Journal of Engineering and Manufacturing Technology vol. 1: 36-44 
Akintola, F.A. (1982). Geology and Geomorphology in Nigeria in Map. Edited by K.M. Barhous, Hodder and Stoughton London.

Alireza, S. G. S., Mohammad, M. S., and Hasan, B. M., (2013). Application of nanomaterial to stabilize a weak soil. International conference on case Histories in Geotechnical Engineering. https://scholarsmine.mst.edu/icchge/7icchge/session 06/5.

Al-Swaidani, A. M., Hammoud, I., Al-Ghoraibi, I. and Meziab, A. (2019). Effect of adding nanocalcined clay and nano-lime on the geotechnical properties of expansive clayey soil. 7th International Conference on Euro Asia Civil Engineering Forum. IOP Conf. Series: Materials Science and Engineering 615:012058, doi:10.1088/1757-899X/615/1/012058

ASTM (1992). Annual Book of Standards. Vol. 04.08, American Society for Testing and Materials. Philadelphia.

Bahmani, S.H., Huat, B. B. K., Asadi, A, and Farzadnia, N. (2014). Stabilization of residual soil using $\mathrm{SiO}_{2}$ nanoparticles and cement. Construction and Building Materials. Vol 64, pp 350-359.

BS 1377 (1990). Method of Testing Soils for Civil Engineering Purpose. British Standard Institute, BSI, London.

Casagrande, A. (1936). The Determination of the pre-consolidation load and its practical significance. Proceedings of the International Conference on soil Mechanics and Foundation Engineering. 3. Harvard university of Cambridge, pp 60-64.

Choobbasti, A.J., Tavakoli, H. and Kutanaei, S. S., (2014). Modelling and optimization of a trench layer location around a pipeline using artificial neural networks and particle swarm optimization algorithm. Tunnelling and Underground Space Technology Vo.1 40, pp. 192-202.

Choobbasti, A. J., Vafaei, A. and Kutanaei, S. S. (2015). Mechanical properties of sandy soil improved with cement and nanosilica. Open Engineering Vol. 5, No 1, pp.111-116.

Eberemu, A. O. (2011). Consolidation Properties of Compacted lateritic soil treated with rice husk ash. Geomaterials, Vol. 1, No.3, pp. 70-78. doi:10.4236/gm.2011.13011.

Eswaramoorthi, P., Kumar, V. S. and Prabhu, P. S., Prabu, T., Lavanya, S. (2017). Influence of nanosized silica and lime particles on the behaviour of soil. International Journal of Civil Engineering and Technology (IJCIET), Vol. 8, No 9: pp. 353-360, Article ID: IJCIET_08_09_041.

Ganesh, V. K., (2012). Nanotechnology in civil engineering. European Scientific Journal, Vol. 8, No. 27, pp. 96-109.

Ghasabkolaei, N., Janalizadeh, A., Jahanshahi, M., Roshan, N. and Ghasemi, S.E. (2016). Physical and geotechnical properties of cement-treated clayey soil using silica nanoparticles: an experimental study. The European Physical Journal Plus Vol. 131, No. 5. http:// dx.doi.org/10.1140/epjp/i2016-16134-3.

Ghazi, H., Baziar, M.H., Mirkazemi, S.M., (2011). The effects of nano-material additives on the basic properties of soil, 14th Asian Regional Conference of Geotechnic, Hong-Kong.

Gidigasu, M.D (1976). Laterite Soil Engineering:Pedogenesis and Engineering Principles. Elsevier Scientific Publication Company, Amsterdam.

Head, K.H (1994). Manual of Soil Laboratory Testing Vol.1 and 2 Pentech Press, London, Plymouth.

Kazemian, S. and Huat, B. B. K. (2009). Compressibility characteristics of fibrous tropical peat with reinforced with cement column. Electronic Journal of Geotechnical Engineering. Vol. 14, Bundle C: 1-13.

Lee, J., Mahendra, S. H. and Alvarez, P. J. J., (2010). Nanomaterials in the construction industry: A review of their applications and environmental health and safety considerations. ACS Nano, Vol. 4, No 7. pp 3580-3590

Lv, J., Christie, P., and Zhang, S. (2019). Uptake, translocation, and transformation of metal-based nanoparticles in plants: Recent Advances and Methodological Challenges. Environmental Science Nano 6, 41-59. doi: 10.1039/C8EN00645H 
Li, G. (2004). Properties of high-volume fly ash concrete incorporating nano $\mathrm{SiO}_{2}$. Cement and Concrete Research, Vol. 34 No. 6 pp 1043-1049. DOI: 10.1016/j.cemconres.2003.11.013

Mashhadban, H., Beitollahi, A. and Kutanaei, S. S., (2016a). Identification of soil properties based on accelerometer records and comparison with other methods. Arabian Journal of Geosciences. Vol. 9, No. 6, pp 1-8.

Mashhadban, H., Kutanaei, S. S. and Sayarinejad, M. A. (2016b). Prediction and modelling of mechanical properties in fiber reinforced self-compacting concrete using particle swarm optimization algorithm and artificial neural network. Construction and Building Materials, Vol. 119, pp. 277-287.

Nicholson, P. G., Kashyap, V. and Fuji, C. F. (1994). Lime and fly ash admixture improvement of tropical hawaiian soil. Transport Research Record. No. 1440. National Academy press, Washington D.C.

NSTC_-National Science and Technology Council. (Dec 2007). Committee of Technology; Subcommittee on Nanoscale Science, Engineering, and Technology. The National Nanotechnology Initiative Strategic Plan. Washington, DC: National Nanotechnology Coordination Office.

Nabanita, D. Arup, B. and Rituparna, G. (2016). Effect of rice husk ash on shear and consolidation of lateritic soil. Indian Geotechnical Conference IGC2016 15-17Ｄecember２016, IIT Madras, Chennai, India.

Osinubi, K. J. (1998). Permeability of lime-treated lateritic soil. Journal of Transportation Engineering, ASCE, Vol.124, No. 2, pp 465-469.

Osinubi, K. J. (1998a). Influence of compactive efforts and compaction delays on lime treated soil. Journal of Transportation Engineering, ASCE, Vol. 124, No. 2, pp. 149 - 155. 12.

Osinubi, K. J. (1998b). Influence of compaction delay on the properties of cement stabilised lateritic soil. Journal of Engineering Research, Vol. JER-6, No. 1, pp.13 - 26.

Osinubi, K. J. and Nwaiwu, M. O. C. (2006). Compaction delay effects on properties of lime-treated soil. Journal of Material in Civil Engineering, ASCE, Vol. 18, No. 2. pp. 250-258.

Osinubi, K. J., Eberemu, A. O. and Aliu, O. S. (2007a). Stabilization of laterite with cement and bagasse ash admixture. Proceeding First International Conference on Environmental Research, Technology Policy 'ERTEP 2007', under the auspices of International Society of Environmental Geotechnology, Category B: Mining and Environment, 6-19 July, Accra, Ghana, p $1-14$.

Osinubi, K.J., Eberemu, A.O. and Kasham, L.S. (2007b). Influence of bagasse ash content on the hydraulic conductivity of compacted lateritic soils at reduced proctor effort. Proceedings of BiMonthly Meetings/Workshops, Materials Society of Nigeria (MSN) Zaria Chapter, ABU Zaria, Nigeria, pp.17-25.

Papatzani, S., Paine, K. and Calabria-Holley J. (2014). The effect of the addition of nanoparticles of silica on the strength and microstructure of blended Portland cement pastes. In: Proceedings of the 2014 international concrete sustainability conference.

Pham, H. and Nguyen, Q. P. (2014). Effect of silica nanoparticles on clay swelling and aqueous stability of nanoparticle dispersions. Journal of Nanoparticle Research 16:2137. https//doi.org/10.1007/s11051-013-2137-9

Ramesh, V. B., Chandrika, K. (2017). A study on strength properties of expansive soil treated with lime and nano silica. International Journal of Science and Research (IJSR) 6 (10): 64-67.

Ran, K., Fanyu, Z., Gonghui, W. and Jianbing, P. (2018). Stabilization of Loess Using $\mathrm{Nano}^{-\mathrm{SiO}_{2}}$. Materials, 11, 1014; doi:10.3390/ma11061014

Salwa, S. S., Abd El-Meguid, F. L., Hebaturahman, A. (2015). Review of nano additives in stabilization of soil. Seventh International Conference on Nano-Technology in Construction. Housing and Building National Research Center HBRC, pp 1-11. 
Sarokolayi, L.K., Beitollahi, A., Abdollahzadeh, G., Amreie, S. T. and Kutanaei, S. S. (2015a). Modelling of ground motion rotational components for near-fault and far-fault earthquake according to soil type. Arabian Journal of Geosciences. Vol. 8, No. 6, pp.3785-97.

Sarokolayi, L. K, Kutanaei S. S., Golafshani S. M., Haji S. R, Mashhadban H. (2015b). Controlvolume based finite element modelling of liquefaction around a pipeline. Geomatics, Natural Hazards and Risk Vol. 7, No. 4, pp.1287-306.

Saurav, (2012). Application of nanotechnology in building materials, International Journal of Engineering Research and Applications, Vol. 2, No. 5, pp. 1077-1082. 